\title{
PEMANFAATAN RUANG BERDASARKAN RENCANA TATA RUANG DALAM UPAYA PERLINDUNGAN KAWASAN TAMAN WISATA ALAM PANTAI
}

\author{
Dede Frastien \\ Wahana Lingkungan Hidup Indonesia (Walhi) Bengkulu \\ frastiend@gmail.com \\ Iskandar; Edra Satmaidi \\ Fakultas Hukum Universitas Bengkulu \\ suttaniskandar@yahoo.com ; edra_fhunib@yahoo.com
}

\begin{abstract}
This study aims to examine the control of utilization of the area of Panjang Bengkulu Beach Nature Park. This non-doctrinal legal research uses the empirical legal approach method. Based on the results of the study, it can be concluded that there has been a deviation in the use of the area of the Nature Tourism Park in Bengkulu Province, as the number of erected buildings is not by following the functions of the Nature Tourism Park. The Provincial Government of Bengkulu has not been consistent in implementing Regional Regulation Number 2 of 2012 concerning the Bengkulu Province Spatial Plan for 2012-2023, which is evident in Article 23 point $\mathrm{d}$ which reads "the construction of new power plants, including Steam Power Plants (PLTU) in Napal Putih "but in the planning it was built in the area of Pantai Panjang Nature Park which is a protected area.
\end{abstract}

Keywords: Protection; Region; Nature Park

\begin{abstract}
Abstrak
Penelitian ini bertujuan untuk mengkaji pemanfaatan kawasan pantai sebagai Taman Wisata Alam. Penelitian ini merupakan penelitian hukum non-doktrinal dengan menggunakan metode pendekatan hukum empiris. Berdasarkan hasil penelitian, dapat disimpulkan bahwa telah terjadi penyimpangan dalam penggunaan kawasan Taman Wisata Alam di Provinsi Bengkulu, karena jumlah bangunan yang dibangun tidak dengan mengikuti fungsi dari Taman Wisata Alam. . Pemerintah Provinsi Bengkulu belum konsisten dalam mengimplementasikan Peraturan Daerah Nomor 2 Tahun 2012 tentang Rencana Tata Ruang Provinsi Bengkulu untuk 2012-2023. Dalam Pasal 23 huruf d peraturan tersebut telah menetapkan bahwa pembangunan pembangkit listrik baru, termasuk Pembangkit Listrik Tenaga Uap (PLTU) di Napal Putih. Tetapi dalam pelaksanaannya di pembangkit listrik tenaga uap yang telah direncanakan justru dibangun di kawasan Taman Wisata Alam Pantai Panjang yang merupakan kawasan lindung.
\end{abstract}

Kata Kunci: Perlindungan; Kawasan; Taman Wisata Alam

\section{PENDAHULUAN}

Keanekaragaman sumber daya alam hayati yang berbentuk dalam suatu ekosistem saling mempunyai keterkaitan, ketergantungan antara satu dengan yang lain seyogyanya dijaga keberadaan dan kesinambungannya agar tetap berada dalam kondisi selaras, serasi dan seimbang. Itulah sebabnya Pasal 33 ayat (3) Undang-Undang Dasar Negara Republik Indonesia Tahun 1945 sejak dini telah meletakan landasan

Dede Frastien: Pengendalian Pemanfaatan Ruang Kawasan Taman Wisata Alam Pantai Panjang Provinsi Bengkulu 
konstitusional pemanfaatan sumber daya alam hayati dan ekosistemnya di Indonesia. ${ }^{1}$

Salah satu upaya untuk menjaga keberadaan dan keberlanjutan sumberdaya alam hayati, negara membagi beberpa kawasan hutan. Kawasan hutan adalah wilayah tertentu yang ditunjuk dan/atau ditetapkan oleh pemerintah untuk dipertahankan keberadaannya sebagai hutan tetap. Kawasan hutan Negara, statusnya secara hukum bahwa hutan tersebut hutan milik Negara. Kawasan hutan Negara tidak selalu berhutan, sehingga peningkatan kawasan hutan dapat berarti secara hukum kawasan hutan Negara naik jumlahnya. Pada tahun 1984 kawasan hutan Negara ditetapkan berdasarkan Tata Guna Hutan Kesepakatan (TGHK) pada tahun 1997 kawasan hutan Negara setelah dilakukan paduserasi antara TGHK dengan RTRWP. ${ }^{2}$

Hutan konservasi terdiri dari kawasan hutan Suaka Alam (KSA) berupa Cagar Alam (CA) dan Suaka Margasatwa (SM); Kawasan hutan Pelestarian Alam (KPA) berupa Taman Nasional (TN), Taman Hutan Raya (Tahura) dan Taman Wisata Alam (TWA); dan Taman Buru (TB). Kawasan hutan Suaka Alam (KSA) adalah hutan dengan ciri khas tertentu yang mempunyai fungsi pokok sebagai kawasan pengawetan keanekaragaman tumbuhan dan satwa serta ekosistemnya, dan juga berfungsi sebagai wilayah sistem penyangga kehidupan. ${ }^{3}$

Pasal 1 angka 16 Undang-Undang Nomor 5 tahun 1990 tentang Konservasi Sumber Daya Alam Hayati dan Ekosistemnya, menyebutkan taman wisata alam adalah kawasan pelestarian alam yang terutama dimanfaatkan untuk pariwisata dan rekreasi alam. Selain untuk kegiatan pariwisata, taman wisata alam mempunyai fungsi melindungi sistem penyangga kehidupan bagi daerah sekitarnya. Bisa juga menjadi tempat pendidikan alam dan pengembangan ilmu pengetahuan. Segala pemanfaatan sumber daya hayati di areal ini harus dimanfaatkan secara lestari.

Di Provinsi Bengkulu terdapat 5 (lima) kawasan Taman Wisata Alam, yang sesuai dengan kriterianya dan memiliki ciri khas tertentu sehingga ditunjuk sebagai taman wisata alam, adapun taman wisata alam di Provinsi Bengkulu sebagai, berikut: (1) TWA Bukit Kaba Rejang Lebong (13.490 ha); (2) TWA Pantai Panjang Kota Bengkulu (967,2 ha); (3) TWA Way Hawang Kaur (94 ha); (4) TWA Air Hitam Muko-Muko (433 ha); (5) TWA Lubuk Tapi-Kayu Ajaran Bengkulu Selatan (6 ha).

Taman Wisata Alam (TWA) Pantai Panjang ditunjuk sebagai taman wisata alam sejak tahun 1995 melalui penunjukkan berdasarkan Surat Keputusan Menteri Kehutanan No. 383/Kpts-II/1985 tanggal 27 Desember

1 Abdulah Marlang dan Rina Maryana, Hukum Konservasi Sumber Daya Alam Hayati dan Ekosistemnya, Mitra Wacana Media, Jakarta, 2015, hlm. 7.

2 Iskandar, Hukum Kehutanan, CV. Mandar Maju, Bandung, 2015, hlm 1.

3 Ibid, hlm. 2.

Dede Frastien: Pengendalian Pemanfaatan Ruang Kawasan Taman Wisata Alam Pantai Panjang Provinsi Bengkulu 
1985 panjang 32,30 km. Penunjukkan tersebut diperkuat oleh Surat Keputusan Gubernur tanggal 28 Januari 1991 Nomor 13 tahun 1991.

Taman Wisata Alam Pantai Panjang telah ditata batas sesuai Berita Acara Tata Batas (BATB) tanggal 30 Maret 1991 yang disahkan Menteri Kehutanan tanggal 10 Juni 1992. Pada tahun 1999 keluar Surat Keputusan Menteri Kehutanan No. 420/Kpts-II/1999 tentang Penunjukkan Kawasan Hutan di Wilayah Provinsi Bengkulu seluas 920.964 ha, dengan luas Taman Wisata Alam Pantai Panjang 967,2 ha. 4 Selanjutnya dilakukanlah pengukuran dan pemancangan batas definitif perubahan batas kawasan, pada tanggal 11 April 2007 dan ditanda tangani tanggal 19 Juni 2007, disahkan oleh Menteri Kehutanan pada tanggal 23 Januari 2009 dengan luas $720 \mathrm{Ha}$. $720 \mathrm{Ha}$ tersebut menjadi luas akhir yang dipakai sampai sekarang, hal tersebut diperkuat oleh SK Menteri Kehutanan Nomor 643/Menhut-II/2011 tanggal 10 November 2011 dan SK Menteri Kehutanan Nomor 784/Kpts-II/2012 tanggal 27 Desember 2012 Keputusan Direktur Jendral Perlindungan Hutan dan Konservasi Alam Nomor SK.1382/IVSet/2014, tanggal 24 Juni 2014 tentang Penataan Blok Taman Wisata Alam Pantai Panjang Pulau Baai Kota Bengkulu seluas 720 Ha. ${ }^{5}$

Di Kawasan Taman Wisata Alam Pantai Panjang sebagian besar perencanaan pembangunan dan pembangunan fisik yang tidak mengacu pada Rencanaan Tata Ruang Wilayah Provinsi. Perencanaan pembangunan adalah suatu proses untuk menentukan tindakan masa depan yang tepat melalui urutan pilihan, dengan memperhitungkan sumber daya yang tersedia, yang dituangkan dalam suatu dokumen sebagai panduan bagi para pelaku pembangunan untuk mencapai tujuan Negara. 6 Struktur perencanaan pembangunan di Indonesia, berdasarkan hierarki dimensi waktunya mengacu pada Undang-Undang Nomor 25 Tahun 2004 tentang Sistem Perencanaan Pembangunan Nasional (SPPN), yang dibagi menjadi Rencana Pembangunan Jangka Panjang Daerah (RPJP-D), Rencana Pembangunan Jangka Menengah Daerah (RPJM-D) dan Rencana Kerja Pemerintah Daerah (RKPD) serta Rencana Strategis Satuan Kerja Perangkat Daerah (Renstra-SKPD) dan Rencana Kerja Perangkat Daerah (Renja-SKPD) sebagai kelengkapannya. ${ }^{7}$

Rencana Tata Ruang Wilayah Provinsi menjadi acuan bagi instansi pemerintah daerah serta masyarakat untuk mengarahkan lokasi dan memanfaatkan ruang dalam menyusun program pembangunan yang berkaitan dengan pemanfaatan ruang di daerah yang bersangkutan. Selain

\footnotetext{
${ }^{4}$ http://www.konservasionis.com/2016/05/eksplorasi-twa-pantai-panjangkoservasi.html diunduh pada hari Jum'at 24/03/2017 pukul 19:20 WIB

${ }^{5}$ BKSDA Bengkulu, Ekspose Hasil Kegiatan Identifikasi dan Potensi Konflik di TWA Pantai Panjang Pulau Baai Reg. 91 Kota Bengkulu, Laporan Perjalanan Dinas, BKSDA Bengkulu, Bengkulu, 2015, hlm. 2.

6 Hanif Nurcholis dkk, Perencanaan Partisipatif Pembangunan Daerah, PT. Gramedia Widiasarana Indonesia, Jakarta, 2009, hlm. 18.

${ }^{7}$ Iskandar, Op.cit., hlm. 126.
}

Dede Frastien: Pengendalian Pemanfaatan Ruang Kawasan Taman Wisata Alam Pantai Panjang Provinsi Bengkulu 
itu, rencana tersebut menjadi dasar dalam memberikan rekomendasi pengarahan pemanfaatan ruang. Rencana tata ruang wilayah provinsi dan rencana pembangunan jangka panjang Provinsi serta pembangunan jangka menengah provinsi merupakan kebijakan daerah yang saling mengacu. ${ }^{8}$

Undang-Undang Nomor 26 Tahun 2007 tentang Penataan Ruang menyatakan bahwa pembinaan penataan ruang meliputi pembinaan aparatur pemerintah dan masyarakat di bidang penyusunan rencana tata ruang, pemanfaatan ruang, dan pengendalian pemanfaatan ruang oleh instansi yang diberi tugas dalam penataan ruang. Memperhatikan beberapa kebijakan pembangunan Provinsi Bengkulu, seperti Rencana Pembangunan Jangka Panjang (RPJP) dan RTRW Provinsi Bengkulu 2012-2032 yang diundangkan kedalam Peraturan Daerah Provinsi Bengkulu Nomor 02 Tahun 2012 tentang Rencana Tata Ruang Wilayah Provinsi Bengkulu. Pergeseran fungsi ruang yang terjadi di Provinsi Bengkulu juga menimbulkan berbagai penurunan kualitas lingkungan. Beberapa permasalahan yang terkait dengan adanya perubahan pemanfatan ruang atau pemanfaatan ruang yang kurang sesuai dengan daya dukung lingkungan telah menimbulkan kerusakan lingkungan dan kerugian yang dirasakan langsung oleh masyarakat.

Implikasinya, meskipun dinyatakan bahwa perencanaan tata ruang merupakan matra spesial dari perencanaan pembangunan, dalam praktik ditemui potensi jarak atau gap bahkan potensi distorsi antara perencanaan tata ruang dan perencanaan pembangunan. Hal ini dapat ditemui pada saat pembahasan tentang RTRW Provinsi/Kabupaten/Kota, serta RPJP-D dan RPJM-D, bahwa pembahasan tentang hubungan antara rencana pembangunan dan rencana tata ruang tidak dijelaskan dengan memuaskan. Ketidak jelasan ini mengakibatkan sulitnya memberikan jawaban atas pertanyaan seberapa jauh rencana tata ruang dapat dilaksanakan meski fakta dilapangan menunjukan bahwa seringkali terjadi bahwa antara perancanaan ruang dengan pelaksanaan pembangunan seringkali tidak sejalan, artinya perencanaan pembangunan tidak mengikuti apa yang telah direncanakan dalam perencanaan atau penataan ruang yang telah ditetapkan. Persoalan lain yang timbul yaitu bagaimana cara untuk melaksanakan praktik di lapangan bahwa harus "memperhatikan" dan harus "mengacu" sedemikian rupa, sehingga terjadi keselarasan atau harmonisasi antara RPJP dan RPJM dengan RTRW. Harapannya yaitu bahwa RPJP dapat diintegrasikan dalam matra spesial dalam kurun waktu 20 (dua puluh) tahun dalam bentuk RTRW. Peluang Semacam ini menjadi semakin lebih besar jika RPJP memuat substansi sektoral sekaligus juga

8 Hasni, Hukum Penataan Ruang dan Penatagunaan Tanah ,Edisi Kedua, PT RajaGrafindo Persada, Jakarta, 2010. hlm. 174. Iskandar, Op.cit., hlm. 126.

8 Hasni, Hukum Penataan

Dede Frastien: Pengendalian Pemanfaatan Ruang Kawasan Taman Wisata Alam Pantai Panjang Provinsi Bengkulu 
implikasi keruangannya dalam bagian skenario 5 (lima) tahunan, yang diikuti secara konsisten. ${ }^{9}$

Taman Wisata Alam Pantai Panjang Bengkulu berfungsi sebagai Kawasan pelestarian alam yang terutama dimanfaatkan untuk pariwisata dan rekreasi alam. Namun implementasi Taman Wisata AlamPantai Panjang banyakketidak sesuaian dengan apa yang diamanatkan oleh UndangUndang Nomor 5 tahun 1990 tentang Konservasi Sumber Daya Alam Hayati dan Ekosistemnya didalam Kawasan Taman Wisata Alam Pantai Panjang masih banyak terdapat pembangunan yang tidak sesuai dengan fungsi Taman Wisata Alam lagi contohnya Areal Bisnis Swasta seperti Lapangan Golf serta terdapat banyak pemukiman warga di kawasan taman wisata alam pantai panjang terlebih lagi areal bisnis Lapangan Golf serta pemukiman warga tersebut berdiri di wilayah lindungTaman Wisata Alam Pantai Panjang Bengkulu dan terdapat kebun sawit warga, lebih parahnya lagi rencana Pembangunan Pembangkit Listrik Tenaga Uap (PLTU) yang tidak sesuai dengan fungsi Taman Wisata Alam Pantai Panjang,dalam melakukan Pembangunan Pemerintah Provinsi Bengkulu sering sekali tidak memperhatikan fungsi Taman Wisata Alam.

Rencana pembangunan yang akan dilakukan di Provinsi Bengkulu tepatnya di Taman Wisata Alam Pantai Panjang,terkhusus di Kelurahan Teluk Sepang merupakan ancaman terbesar bagi ekosistem dan sumber daya alam di sekitarnya terlebih lagi Rencana Pembagunan Provinsi Bengkulu di kawasan Taman Wisata Alam Pantai Panjang tersebut bertentangan dengan regulasiyang terkait seperti pembangunan Pembangkit Listrik Tenaga Uap (PLTU) pada dasarnya pembangunan PLTU yang akan dilakukan di Kelurahan Teluk Sepang Provinsi Bengkulu bertentangan dengan Peraturan Daerah Provinsi Bengkulu Nomor 02 Tahun 2012tentang Rencana Tata Ruang Wilayah Provinsi Bengkulu,pada bagian keempat Perda RTRW Provinsi Bengkulu mengatur mengenai Rencana dan Kriteria Sistem Jaringan Energi dimana di dalam Paragraf 1 mengenai Rencana SistemJaringan Energi yang terdapat dalam Pasal 23 butir d yang berbunyi "Pembangunan listrik pembangkit baru, meliputi Pembangkit Listrik Tenaga Uap (PLTU) di Napal Putih" dan selain itu juga bertentangan dengan Peraturan Presiden RI Nomor 13 Tahun 2012 Tentang Rencana Tata Ruang Wilayah Pulau Sumatera mengingat di dalam Rencana Tata Ruang Wilayah Pulau Sumatera tidak ada pembangunan PLTU yang akan dilakukan di Provinsi Bengkulu.

Menurut Badan Perencanaan Pembangunan Daerah Provinsi Bengkulu melalui Kasub Penataan Ruang mengatakan rencana pembangunan PLTU tersebut sudah dilakukan Kajian Lingkungan Hidup Strategis (KLHS). 10 Namun pada kenyataannya rencana pembangunan

9 Iskandar, Op.cit., hlm. 176.

10 Kasub Penataan Ruang, Dinas Badan Perencanaan Pembangunan Daerah Provinsi Bengkulu, Wawancara di Bengkulu, tanggal 19-Juni-2017.

Dede Frastien: Pengendalian Pemanfaatan Ruang Kawasan Taman Wisata Alam Pantai Panjang Provinsi Bengkulu 
tersebut haruslah memperhatikan daya dukung dan daya tampung Taman Wisata Alam Pantai Panjang yang tertuang melalui Kajian Lingkungan Hidup Strategis (KLHS) dan mengacu pada Rencana Tata Ruang Wilayah Provinsi Bengkulu yang tertuang dalam Peraturan Daerah Nomor 02 Tahun 2012 tentang Rencana Tata Ruang Wilayah Provinsi Bengkulu tahun 20122032.Proses integrasi KLHS yang hanya dilakukan pada tahap analisis data menyebabkan penyusunan KLHS tidak dapat dilakukan berbarengan dengan proses penyusunan RTRW. Penyusunan KLHS baru dilakukan setelah proses penyusunan RTRW sudah separuh atau bahkan sudah hampir rampung disusun. Konsekuensi lain dari proses integrasi KLHS yang hanya dilakukan pada tahapan analisis adalah jaminan integrasi analisis daya dukung dan daya tampung lingkungan hidup (yang menjadi muatan KLHS RTRW) dalam proses penyusunan konsepsi RTRW provinsi dan dalam proses penyusunan raperda (berupa rumusan pasal-pasal) RTRW provinsi, sehingga ada kemungkinan rekomendasi KLHS untuk perbaikan KRP RTRW tidak ada jaminan pengintegrasiannya dalam Raperda RTRW Provinsi. ${ }^{11}$ Berdasarkan persoalan tersebut, penelitian ini bertujuan untuk mengkaji Pengendalian Pemanfaatan Ruang Dalam Rangka Perlindungan Kawasan Taman Wisata Alam Pantai Panjang Provinsi Bengkulu.

\section{METODE PENELITIAN}

Penelitian ini merupakan penelitian hukum dengan pendekatan empiris, yang berupaya menjelaskan dan menjabarkan tentang Pengendalian Pemanfaatan Ruang Dalam Rangka Perlindungan Kawasan Taman Wisata Alam Pantai Panjang di Provinsi Bengkulu. Lokasi penelitian di Kota Bengkulu. Pengumpulan data dilakukan dengan pengamatan, wawancara untuk memperoleh data primer, dan didukung data sekunder melalui studi pustaka. Data sekunder meliputi peraturan perundangundangan terutama Peraturan Daerah Provinsi Bengkulu Nomor 02 Tahun 2012 Tentang Rencana Tata Ruang Wilayah Provinsi Bengkulu Tahun 20122032 dan dokumen hukum lainnya.

\section{HASIL DAN PEMBAHASAN}

\section{Dasar Hukum Status Kawasan Taman Wisata Alam}

Taman Wisata Alam khususnya Pantai Panjang yang terletak di Kota Bengkulu telah beberapa kali mengalami perubahan ukuran luas hutan. Pertama kali penunjukan kawasan pada tanggal 27 Desember 1985 dengan Surat Keputusan Menteri Kehutanan Nomor. 383/Kpts-II/1985 seluas $1.265,3 \mathrm{Ha}$, dan Panjang 32,30 km. Selanjutnya penunjukkan diperkuat dengan Surat Keputusan Gubernur tanggal 28 Januari 1991 No. 13 tahun

11 Edra Satmaidi, "Kajian Lingkungan Hidup Strategis (KLHS) dalam Menjamin Terpeliharanya Daya Dukung dan Daya Tampung Lingkungan Hidup (DDDTLH) Bagi Pembangunan Berkelanjutan", Indonesian Journal Of Dialectics, vol. 5, No 3 Desember 2015, hlm. 130.

Dede Frastien: Pengendalian Pemanfaatan Ruang Kawasan Taman Wisata Alam Pantai Panjang Provinsi Bengkulu 
1991. Tata Batas Kawasan, sesuai dengan Berita Acara Tata Batas (BATB) tanggal 30 Maret 1991, dan disahkan oleh Menteri Kehutanan tanggal 10 Juni 1992. Tetapi dalam perjalanannya Taman Wisata Alam Pantai Panjang mengalami penyusutan luas wilayah hutan, oleh karena itu pada tanggal 15 Juni 1999 dilakukan pengukuran kembali dan hasilnya seluas 967,2 Ha. Kemudian disahkan dengan SK Menteri Kehutanan Nomor 420/KptsII/1999. Lebih lanjut dilakukan pengukuran dan pemancangan batas definitif perubahan batas kawasan, pada tanggal 11 april 2007 dan ditanda tangani tanggal 19 Juni 2007, dan disahkan oleh Menteri Kehutanan tanggal 23 Januari 2009 dengan luas 720 Ha. Hal tersebut diperkuar oleh SK Menteri Kehutanan Nomor 643/Menhut-II/2011 tanggal 10 November 2011 dan SK Menteri Kehutanan Nomor 784/Kpts-II/2012 tanggal 27 Desember 2012 Keputusan Direktur Jendral Perlindungan Hutan dan Konservasi Alam Nomor SK.1382/IV-Set/2014, tanggal 24 Juni 2014 tentang Penataan Blok Taman Wisata Alam Pantai Panjang Pulau Baai Kota Bengkulu seluas 720 Ha. Status Taman Wisata Alam Pantai Panjang yang baru "penunjukan" belum mendapatkan pengukuhan dan penetapan dari Menteri Kehutanan dan Lingkungan Hidup. ${ }^{12}$ Sehingga dapat disimpulkan bahwa luas Taman Wisata Alam Pantai Panjang masih menggunakan luas yang lama dengan SK Menteri Kehutanan Nomor 420/Kpts-II/1999, luas 967,2 Ha.

Menurut Kepala Badan penelitian dan Pengembangan Hutan Balai Konservasi Sumber Daya Alam Bengkulu, bahwa perubahan luas kawasan Taman Wisata Alam Pantai Panjang yang pertama kali dikarenakan perubahan fungsi kawasan hutan menjadi Areal Penggunaan Lain (APL) oleh pemerintah Provinsi Bengkulu pada tahun 2007 silam, sehingga luas Taman Wisata Alam Pantai Panjang yang semula memiliki luas 1.265,3 Ha mengalami penyusutan hingga 967,2 Ha. Faktor-faktor lain yang mempengaruhi berkurangnya luas Taman Wisata Alam Pantai Panjang adalah tumpang tindih kawasan dengan pihak PT. PELINDO II yang di perkuat olehsertifikat Hak Pengelolaan Lahan (HPL) milikPT. PELINDO II sejak tahun 1973 seluas 230 Ha konflik tersebut sampai saat ini belum terselesaikan. 13

Taman Wisata Alam yang terutama dimanfaatkan untuk kepentingan pariwisata alam dan rekreasi berdasarkan Pasal 1 angka 11 Peraturan Pemerintah Nomor 108 Tahun 2015 tentang Pengelolaan Kawasan Suaka Alam dan Kawasan Pelestarian Alam, pada Pasal 1 angka 36 Peraturan Daerah Provinsi Bengkulu Nomor 02 tahun 2012 tentang Rencana Tata Ruang Wilayah Provinsi Bengkulu tahun 2012-2032, pada Taman Wisata Alam Pantai Panjang dalam kenyataannya belum

12 BKSDA Bengkulu, Ekspose Hasil Kegiatan Identifikasi dan Potensi Konflik di TWA Pantai Panjang Pulau Baai Reg 91 Kota Bengkulu, Laporan Perjalanan Dinas, BKSDA Bengkulu, Bengkulu, 2015. hlm.2.

13 Kepala Badan Penelitian dan Pengembangan Hutan Balai Konservasi Sumber Daya Alam Bengkulu, Wawancara di Bengkulu, tanggal 13-Juni-2017.

Dede Frastien: Pengendalian Pemanfaatan Ruang Kawasan Taman Wisata Alam Pantai Panjang Provinsi Bengkulu 
terimplementasikan dengan baik, berdasarkan hasil wawancara terbuka kepada Dinas Pariwisata Provinsi Bengkulu melalui Kepala Bidang Destinasi Pariwisata mengatakan belum terdapat pemanfaatan destinasi pariwisata alam dan rekreasi alam di kawasan Taman Wisata Alam Pantai Panjang, dikarenakan pembangunan dan destinasi pariwisata pada Pantai Panjang terfokus kepada Areal Penggunaan Lain (APL) yaitu daerah Sport Centerhingga pasir putih, didalam kawasan Taman Wisata Alam Pantai Panjang pemanfaatan ruang sebagai sarana pariwisata dan rekreasi alam tidak pernah dilakukan oleh pemerintah daerah Provinsi Bengkulu, terdapat rekreasi alam yaitu Out Boundt yang pengelolaannya dikelola oleh pihak swasta dan bukan aset daerah pemerintah Provinsi Bengkulu. ${ }^{14}$

Pada Pasal 37 Peraturan Pemerintah Nomor 108 Tahun 2015, menyebutkan bahwa Taman Wisata Alam dapat dimanfaatkan sebagai berikut: (a) Penyimpanan dan/atau penyerapan karbon, pemanfaatan air, energi air, angin, panas matahari, panas bumi, dan wisata alam; (b)Penelitian dan pengembangan ilmu pengetahuan; (c) Pendidikan dan peningkatan kesadartahuan konservasi alam; (d) Pemanfaatan sumber plasma nutfah untuk penunjang budidaya; (e). Pembinaan populasi dalam rangka penetasan telur dan/atau pembesaran anakan yang diambil dari alam; dan (f). Pemanfaatan tradisional oleh masyarakat setempat;

Pemerintah Provinsi Bengkulu seharusnya melakukan pemanfaatan destinasi pariwisata dan rekreasi alam di kawasan Taman Wisata Alam Pantai Panjang, dan lebih memfokuskan kepada pembangunan yang berdampak positif terhadap kawasan Taman Wisata Alam sehingga fungsi Taman Wisata Alam dapat terjaga dan lestari, namum pada kenyataannya pemerintah Provinsi Bengkulu banyak sekali melakukan pembangunan dan perencanaan pembangunan yang tidak sesuai dengan fungsi Taman Wisata Alam sehingga berakibat merusak ekosistem dan penyangga kehidupan Taman Wisata Alam Pantai Panjang..

Pembangunan dan perencanaan pembangunan yang terjadi di kawasan Taman Wisata Alam Pantai Panjang adalah sebagai berikut:

Tabel : Pembangunan di Taman Wisata AlamPantai Panjang

Bengkulu

\begin{tabular}{|c|c|c|}
\hline No & Pembangunan & Pengelola \\
\hline 1. & Lapangan Golf & $\begin{array}{l}\text { BUMD (Bengkulu Mandiri) } \\
\text { Pemerintah Daerah Provinsi } \\
\text { Bengkulu. }\end{array}$ \\
\hline 2. & $\begin{array}{l}\text { Kolam Pemancingan } \\
\text { (percontohan) }\end{array}$ & $\begin{array}{l}\text { Pemerintah Daerah Provinsi } \\
\text { Bengkulu, dikelola oleh Dinas } \\
\text { Perikanan. }\end{array}$ \\
\hline
\end{tabular}

14 Kepala Bidang Destinasi Pariwisata Dinas Pariwisata Provinsi Bengkulu, tanggal 14-Juni-2017.

Dede Frastien: Pengendalian Pemanfaatan Ruang Kawasan Taman Wisata Alam Pantai Panjang Provinsi Bengkulu 


\begin{tabular}{|c|c|c|}
\hline & $\begin{array}{ll}\text { diperkuat HGU seluas } \\
230 \mathrm{Ha}\end{array}$ & \\
\hline 4. & $\begin{array}{l}\text { Lapangan tembak TNI AL } \\
\text { Bengkulu }\end{array}$ & TNI AL \\
\hline 5. & $\begin{array}{l}\text { Lapangan tembak Polda } \\
\text { Bengkulu }\end{array}$ & Polda Bengkulu \\
\hline 6. & $\begin{array}{l}\text { Perumahan KOREM } \\
\text { GAMAS }\end{array}$ & TNI AD \\
\hline 7. & $\begin{array}{l}\text { Perkantoran UPTD Dinas } \\
\text { Perikanan dan Kelautan, } \\
\text { Provinsi Bengkulu. }\end{array}$ & $\begin{array}{l}\text { Pemerintah Daerah Provinsi } \\
\text { Bengkulu. }\end{array}$ \\
\hline 8. & $\begin{array}{l}\text { Perumahan masyarakat } \\
\text { yang menyebar di dalam } \\
\text { kawasan TWA Pantai } \\
\text { Panjang, permanen } 80 \% \\
\text { dan semi permanen } 20 \% \\
\text { dengan jumlah } 800 \mathrm{KK} \text {, } \\
\text { sudah memiliki Sertifikat } \\
\text { Hak Milik sejak tahun } \\
\text { 1973. }\end{array}$ & $\begin{array}{l}\text { Masyarakat sekitar Taman Wisata } \\
\text { Alam Pantai Panjang. }\end{array}$ \\
\hline 9. & Perkebunan warga & $\begin{array}{l}\text { Masyarakat sekitar Taman Wisata } \\
\text { Alam Pantai Panjang. }\end{array}$ \\
\hline 10. & $\begin{array}{l}\text { Lahan (kampung/desa) } \\
\text { lokalisasi PSK sebanyak } \\
40 \mathrm{KK}\end{array}$ & Pemerintah Kota Bengkulu. \\
\hline 11. & $\begin{array}{l}\text { Perencanaan } \\
\text { Pembangunan } \\
\text { Pembangkit Listrik } \\
\text { Tenaga Uap (PLTU) di } \\
\text { lahan PT. PELINDO II }\end{array}$ & $\begin{array}{l}\text { Pemerintah Provinsi Bengkulu dan } \\
\text { BUMN }\end{array}$ \\
\hline
\end{tabular}

Sumber: Laporan Perjalan Kerja, Balai Konservasi Sumber Daya Alam

Bengkulu, 2015

Untuk mencegah kerusakan serta perubahan fungsi lingkungan hidup terhadap Taman Wisata Alam Pantai Panjang, maka diperlukannya Pengendalian Pemanfaatan ruang dalam rangka perlindungan Taman Wisata Alam Pantai Panjang terhadap bangunan-bangunan dan perencanaan pembangunan yang tidak sesuai dengan fungsi Taman Wisata Alam Pantai Panjang agar Taman Wisata Alam Pantai Panjang terhindar dari kerusakan dan kepunahan.

\section{Pengendalian Pemanfaatan Ruang Dalam Rangka Perlindungan Taman Wisata Alam Pantai Panjang}

Upaya untuk melakukan Pengendalian Pemanfaatan Ruang dalam rangka perlindungan Taman Wisata Alam Pantai Panjang, Balai Konservasi

Dede Frastien: Pengendalian Pemanfaatan Ruang Kawasan Taman Wisata Alam Pantai Panjang Provinsi Bengkulu 
Sumber Daya Alam melalui Kepala Badan Penelitian dan Pengembangan Hutan mengatakan upaya untuk melakukan perlindungan tersebut seharusnya dilakukan dengan cara Pengendalian Pemanfaatan Ruang oleh pemerintah Provinsi Bengkulu karena kawasan Taman Wisata Alam tersebut merupakan kawasan lindung di dalam Peraturan Daerah Nomor 02 tahun 2012 yang mana kawasan lindung tersebut masuk ke dalam penataan ruang Provinsi Bengkulu dan tidak boleh dikeluarkannya Izin Mendirikan Bangunan oleh pemerintah Provinsi Bengkulu. kewenangan pemerintah Provinsi Bengkulu untuk melakukan pengendalian pemanfaatan ruang, pemerintah Provinsi Bengkulu dapat menertibkan bangunanbanguanan yang tidak sesuai dengan fungsi lindung kawasan Taman Wisata Alam Pantai Panjang melalui Peraturan Daerah Nomor 02 Tahun 2012 tentang Rencana Tata Ruang Wilayah Provinsi Bengkulu tahun 20122032 dan menertibkan bangunan yang tidak memiliki Izin Mendirikan Bangunan, sehingga tidak terjadi tumpang tindih kewenangan. ${ }^{15}$ Sedangkan hasil wawancara dengan Dinas Lingkungan Hidup dan Kehutanan Provinsi Bengkulu melalui Kepala Bidang Perancanaan dan Tata Hutan mengatakan bahwa Dinas Kehutanan dan Lingkungan Hidup Provinsi Bengkulu tidak mempunyai wewenang di dalam Taman Wisata Alam Pantai Panjang karena kawasan tersebut merupakan kawasan Hutan Konservasi yang seutuhnya adalah kewenangan dari Balai Konservasi Sumber Daya Alam Bengkulu. ${ }^{16}$

Pengendalian pemanfaatan dalam rangka perlindungan kawasan Taman Wisata Alam Pantai Panjang di seharusnya dilakukan oleh dua belah pihak pemerintah pusat melalui BKSDA merujuk kepada Undang-Undang Nomor 5 Tahun 1990 tentang Konservasi Sumber Daya Alam Hayati dan Ekosistemnya dan Peraturan Pemerintah Nomor 108 Tahun 2015 tentang pengelolaan Kawasan Suaka Alam dan Kawasan Pelestarian Alam.Sedangkan pemerintahProvinsi Bengkulu merujuk kepada UndangUndang Nomor 26 Tahun 2007 tentang Penataan Ruang dan Peraturan Pemerintah Nomor 15 Tahun 2010 tentang Penyelenggaraan Penataan Ruang serta Peraturan Daerah Provinsi Bengkulu Nomor 02 Tahun 2012 tentang Rencana Tata Ruang Wilayah, sehingga BKSDA dan pemerintah Provinsi Bengkulu dapat melaksanakan paduserasi regulasi antara kawasan konservasi yang telah diatur didalam Undang-Undang Nomor 5 Tahun 1990 dan Peraturan Pemerintah Nomor 108 Tahun 2015 dengan peruntukan ruang dan/atau kawasan lidung yang telah diatur kedalam Peraturan Daerah Nomor 02 Tahun 2012, maka pengendalian pemanfaatan ruang dalam rangka perlindungan Taman Wisata Alam Pantai Panjang dapat terwujud serta tidak tumpang tindih.

Undang-Undang Nomor 23 Tahun 2014 tentang Pemerintah Daerah pembagian pemerintah di bidang kehutanan huruf c, menyatakan: "Bagian

15 Kepala Badan Penelitian dan Pengembangan Hutan Balai Konservasi Sumber Daya Alam Bengkulu, Wawancara di Bengkulu, tanggal 13-Juni-2017.

16 Kepala Bidang Perencanaan dan Tata Hutan Dinas Lingkungan Hidup dan Kehutanan Provinsi Bengkulu, Wawancara di Bengkulu, tanggal 16-Juni-2017.

Dede Frastien: Pengendalian Pemanfaatan Ruang Kawasan Taman Wisata Alam Pantai Panjang Provinsi Bengkulu 
konservasi sumber daya alam, kewenangan dipegang olehpemerintah pusat, pemerintah daerah provinsi dan pemerintah kabupaten atau kota". Hal tersebut membuktikan bahwa kewenangan untuk melakukan penertiban tata ruang dalam upaya perlindungan Taman Wisata Alam Pantai Panjang dapat dilakukan oleh pemerintah pusat dan pemerintah daerah dengan melakukan koordinasi dan paduserasi regulasi-regulasi yang terkait terhadap perlindungan Taman Wisata Alam Pantai Panjang.

Pengendalian Pemanfaatan ruang dalam rangka perlindungan Taman Wisata Alam Pantai Panjang, menurut Kepala Bidang Perancanaan dan Tata Hutan Dinas Lingkungan Hidup dan Kehutanan Provinsi Bengkulu, bahwa Dinas Kehutanan dan Lingkungan Hidup tidak mempunyai wewenang di dalam Taman Wisata Alam Pantai Panjang karena kawasan tersebut merupakan kawasan Hutan Konservasi yang seutuhnya adalah kewenangan dari Balai Konservasi Sumber Daya Alam, terkait upaya penertiban bangunan-bangunan pemukiman warga dan areal swasta lapangan golf pemerintah Provinsi Bengkulu sedang melakukan upaya evaluasi kerja namun permasalahan tersebut tidak akan selesai dengan evaluasi kerja saja, dalam hal ini Gubernur Bengkulu meminta kepada Kementerian Kehutanan dan Lingkungan Hidup agar membebaskan kawasan pemukiman warga dan kawasan lapangan golf tersebut dari kawasan Taman Wisata Alam Pantai Panjang. Hal tersebut sudah dilakukan sejak tahun 2014 yang lalu untuk membebaskan pemukiman warga yang masuk ke dalam kawasan Taman Wisata Alam Pantai Panjang. ${ }^{17}$

Berdasarkan uraian dapat dikatakan bahwa pemerintah Provinsi Bengkulu belum konsisten menerapkan beberapa prinsip. Prinsip ecodevelopment memandang dua dimensi dalam satu proses yang saling menunjang dan bereksistensi, pembangunan dapat berguna bagi pengembangan lingkungan yang lebih optimal, tetapi lingkungan hidup dan alam juga berperan dalam menunjang pembangunan, keduanya dapat mencapai perannya jika terdapat prinsip penyerasian. Tidaklah bijaksana apabila keduanya masih dipandang tajam dan proporsi pengeksploitasi dengan yang dieksploitasi antara subjek dan objek pembangunan. Justru dalam prinsip perimbangan telah terkandung makna bahwa kesatuan manusia dan kesatuan lingkungan benar-benar sudah berpadu dalam sistem yang matual assistance atau matual contributing. Apabila telah demikian halnya, maka manusia tidak lagi tepat untuk menggangap dirinya memiliki dominasi yang bersifat mutlak terhadap eksistensi lingkungan alam, manusia dengan lingkungan alam harus sudah siap untuk mencapai "komitmen" atau harus berdamai dengan lingkungannya, dengan cara

17 Kepala Bidang Perencanaan dan Tata Hutan Dinas Lingkungan Hidup dan Kehutanan Provinsi Bengkulu, Wawancara di Bengkulu, tanggal 16-Juni-2017.

Dede Frastien: Pengendalian Pemanfaatan Ruang Kawasan Taman Wisata Alam Pantai Panjang Provinsi Bengkulu 
menyerasikan setiap interaksi dan kemampuan masing-masing agar kehidupan yang berkesinambungan itu tidak mengalami hambatan. ${ }^{18}$

Terkait hal tersebut dijelaskan pada Pasal 64 mengenai arahan zonasi kawasan lindung Peraturan Daerah Provinsi Bengkulu nomor 02 Tahun 2012 tentang Rencana Tata Ruang Wilayah Provinsi Bengkulu tahun 2012-2032, sebagai berikut: "Indikasi arahan peraturan zonasi kawasan resapan air sebagaimanadimaksud dalam pasal 61 ayat (1) huruf c ditetapkan sebagai berikut:

a. Dalam kawasan resapan air tidak diperbolehkan adanya kegiatan budidaya;

b. Permukiman yang sudah terbangun di dalam kawasan resapan air sebelum ditetapkan sebagai kawasan lindung masih diperbolehkan, namun harus memenuhi syarat : (1) Tingkat kerapatan bangunan rendah (KDB maksimum $20 \%$ dan KLB maksimun $40 \%$ ); Perkerasan permukiman menggunakan bahan yang memiliki daya serap air tinggi; (3) Dalam kawasan resapan air apabila diperlukan disarankan dibangun sumur-sumur resapan sesuai ketentuan yang berlaku."

Penjelasan Pasal tersebut mengenai arahan zonasi pada daerah resapan air dalam hal ini Taman Wisata Alam Pantai Panjang seharusnya menjadi acuan bagi pemerintah Daerah Provinsi Bengkulu melalui Dinas Lingkungan hidup dan Kehutanan untuk melakukan pengendalian pemanfaatan ruang dan/atau memenuhi sayarat arahan seperti yang diamanatkan Peraturan Daerah tersebut terhadap pemukiman warga yang sudah berdiri sebelum penunjukan kawasan hutan Taman Wisata Alam Pantai Panjang, sehingga implementasi dari Pasal tersebut dapat memberikan perlindungan terhadap Taman Wisata Alam Pantai Panjang. Dalam hal tersebut pemerintah Provinsi Bengkulu tidak perlu untuk melakukan alih fungsi terhadap kawasan Taman Wisata Alam Pantai Panjang terkait bangunan pemukiman warga yang sudah berdiri sebelum penunjukan kawasan Taman Wisata Alam. Pemerintah Provinsi Bengkulu sudah menerapkan kebijakan yang bersifat mengarahkan artinya pemerintah Provinsi Bengkulu dapat melakukan kombinasi kebijakan yaitu gabungan antara kebijakan yang mengarahkan dengan kebijakan yang mengatur. ${ }^{19}$ Alat dari kebijakan yang mengarahkan tersebut sudah dibuat melalui arahan zonasi pada daerah resapan air, sehingga pemerintah Provinsi Bengkulu tinggal mengarahkannya dan memberikan kemudahan terhadap implementasi dari Peraturan Daerah Nomor 02 Tahun 2012 tentang Arahan Zonasi Ruang tersebut terkait dengan pemukiman warga yang sudah ada sebelum penunjukan kawasan Taman Wisata Alam Pantai Panjang.

18 N.H.T Siahaan, Hukum Lingkungan Ekologi Pembangunan, Jakarta, Penerbit Erlangga, Edisi. 2, hlm.178-179.

19 Robinson Tarigan, Op.cit,. hlm.56.

Dede Frastien: Pengendalian Pemanfaatan Ruang Kawasan Taman Wisata Alam Pantai Panjang Provinsi Bengkulu 
Kelestarian Taman Wisata Alam Pantai Panjang sangat penting, oleh karena itu agar tetap terlindungi maka Pemerintah Provinsi Bengkulu harus melakukan prinsip jaminan kepastian hukum terhadap status kawasan hutan (the principles of legal certainty over the status of forest areas) Suatu kawasan hutan yang telah ditetapkan status hukumnya sebagai kawasan dengan fungsi utamanya fungsi lindung, fungsi konservasi, dan fungsi produksi, maka harus tetap dipertahankan status hukum dari fungsi dimaksud. Setelah ditetapkan status hukumnya sebagai suatu kawasan hutan tertentu, tidak lagi dengan mudah mengubah status tersebut setiap saat dengan berbagai alasan. Kepastian hukum atas status kawasan hutan ini penting, karena dengan status hukum yang pasti akan menjadi instrumen utama dalam proses perlindungan dan pengelolaan suatu kawasan hutan. Tanpa adanya kepastian hukum atas suatu kawasan hutan, maka akan berdampak pada lemahnya perlindungan dan termasuk dalam pengelolaan suatu kawasan hutan. ${ }^{20}$

Kebijakan pemerintah Provinsi Bengkulu dalam rangka untuk melakukan perubahan fungsi Taman Wisata Alam Pantai Panjang bukanlah menjadi solusi terhadap perlindungan Taman Wisata Alam Pantai Panjang yang telah mengalami kerusakan parah berdasarkan data dari Badan Konservasi Sumber Daya Alam melalui Laporan Perjalanan Dinas menyatakan bahwa kawasan yang telah berubah bentuk /fungsi akibat kegiatan (permasalahan) seluas kurang lebih $620 \mathrm{Ha}$, serta yang masih relatif utuh dengan vegetasi sedang-menengah seluas kurang lebih 100 Ha. ${ }^{21}$ Untuk melakukan perubahan fungsi kawasan hutan konservasi menjadi kawasan hutan lindung dan/atau kawasan hutan produksi wajib memenuhi ketentuan: a) Tidak memenuhi kriteria sebagai kawasan hutan konservasi sesuai peraturan perundang-undangan; b) Memenuhi kriteria hutan lindung dan/atau hutan produksi sesuai peraturan perundangundangan. ${ }^{22}$ Apabila dicermati dari hal tersebut solusi dari pemerintah Provinsi Bengkulu untuk melakukan perubahan fungsi Taman Wisata Alam Pantai Panjang akan berakibat kepada kepunahan serta Taman Wisata Alam tidak dapat lagi menjadi penyangga kehidupan dan menghilangkan fungsi lingkungan hidup sebagaimana semestinya. Belum lagi konflik tumpang tindih kawasan dengan PT. Pelindo II Bengkulu yang merupakan lokasi dari perencanaan pembangunan Pembangkit Listrik Tenaga Uap (PLTU) yang sama sekali tidak mengacu kepada Peraturan Daerah Nomor 02 tahun 2012 tentang Rencana Tata Ruang Wilayah Provinsi Bengkulu.

${ }^{20}$ Iskandar, "Aktualisasi Prinsip Hukum Pelestarian Fungsi Lingkungan Hidup Dalam Kebijakan Perubahan Peruntukan, Fungsi, dan Penggunaan Kawasan Hutan", Jurnal Dinamika Hukum, Vol. 11 No. 3, 2011, hlm.16.

${ }^{21}$ BKSDA Bengkulu, Ekspose Hasil Kegiatan Identifikasi dan Potensi Konflik di TWA Pantai Panjang Pulau Baai Reg 91 Kota Bengkulu, Laporan Perjalanan Dinas, BKSDA Bengkulu, Bengkulu, 2015. hlm.2.

22 Iskandar, Hukum Kehutanan, Op.cit. hlm.58.

Dede Frastien: Pengendalian Pemanfaatan Ruang Kawasan Taman Wisata Alam Pantai Panjang Provinsi Bengkulu 
Pembangunan Pembangkit Listrik Tenaga Uap (PLTU) Pada dasarnya akan dilakukan di kawasan PT.PELINDO II yang merupakan daerah resapan air pada peta Pola Tata Ruang Provinsi Bengkulu bertentangan dengan Peraturan Daerah Provinsi Bengkulu Nomor 02 Tahun 2012 Tentang Rencana Tata Ruang Wilayah Provinsi Bengkulu, Pada bagian keempat Peraturan Daerah Nomor 02 Tahun 2012 tentangRencana Tata Ruang Wilayah Provinsi Bengkulu mengatur mengenai Rencana dan Kriteria Sistem Jaringan Energi dimana di dalam Paragraf 1 mengenai Rencana SistemJaringan Energi yang terdapat dalam Pasal 23 butir d yang berbunyi: "Pembangunan listrik pembangkit baru, meliputi Pembangkit Listrik Tenaga Uap (PLTU) di Napal Putih". Selain itu juga bertentangan dengan Peraturan Presiden RI Nomor 13 Tahun 2012 tentang Rencana Tata Ruang Wilayah Pulau Sumatera mengingat di dalam Rencana Tata Ruang Wilayah Pulau Sumatera tidak ada pembangunan PLTU yang akan dilakukan di Provinsi Bengkulu.

Implikasinya, meskipun seringkali dinyatakan bahwa perencanaan tata ruang merupakan matra spesial dari perencanaan pembangunan, dalam prakteknya sering ditemui potensi jarak atau gap bahkan potensi distorsi antara perencanaan tata ruang dan perencanaan pembangunan. mengenai hal ini seringkali ditemui pada saat pembahasan tentang RTRW Provinsi/Kabupaten/Kota, serta RPJP-D dan RPJM-D, bahwa pembahasan tentang hubungan antara rencana pembangunan dan rencana tata ruang tidak dijelaskan dengan memuaskan. Ketidakjelasan ini mengakibatkan sulitnya memberikan jawaban atas pertanyaan seberapa jauh rencana tata ruang dapat dilaksanakan meski fakta dilapangan menunjukan bahwa seringkali terjadi bahwa antara perancanaan ruang dengan pelaksanaan pembangunan seringkali tidak sejalan, artinya perencanaan pembangunan tidak mengikuti apa yang telah direncanakan dalam perencanaan atau penataan ruang yang telah ditetapkan. ${ }^{23}$

Menurut Badan Perencanaan Pembangunan Daerah Provinsi Bengkulu melalui Kasub Penataan Ruang mengatakan ada dasar hukum yang lebih tinggi terhadap rencana pembangunan PLTU tersebut yaitu kesepakatan bersama Menteri dalam hal ini pemerintah pusat, ada beberapa izin yang tidak dapat dihambat dalam melakukan pembangunantermasuk pembangunan pembangkit listrik, hal lain yang menjadi pertimbangan pemerintah Provinsi Bengkulumelakukan rencana pembangunan PLTU tersebut di daerah resapan air yang mana lahan tersebut milik PT. PELINDO II Bengkulu bahwa kawasan tersebut merupakan kawasan industri, sehingga tahun 2017 ini dilakukan Peninjauan Kembali (PK) terhadap Peraturan Daerah Nomor 02 Tahun 2012 dan direkomendasikan dengan penambahan klausul Pasal yang berbunyi bahwa pembangunan sistem jaringan energi boleh dilakukan di seluruh wilayah Provinsi Bengkulu dengan melakukan Kajian Lingkungan Hidup

23Iskandar, Hukum Kehutanan, Op.cit. Hlm.176.

Dede Frastien: Pengendalian Pemanfaatan Ruang Kawasan Taman Wisata Alam Pantai Panjang Provinsi Bengkulu 
Strategis (KLHS). ${ }^{24}$ Namun hal tersebut harus mengacu kepada daya dukung dan daya tampung lingkungan hidup serta pada Peraturan Daerah Provinsi Bengkulu Nomor 02 Tahun 2012 tentang Rencana Tata Ruang Wilayah Provinsi Bengkulu tahun 2012-2032.Proses integrasi KLHS yang hanya dilakukan pada tahap analisis data menyebabkan penyusunan KLHS tidak dapat dilakukan berbarengan dengan proses penyusunan RTRW. Penyusunan KLHS baru dilakukan setelah proses penyusunan RTRW sudah separuh atau bahkan sudah hampir rampung disusun. Konsekuensi lain dari proses integrasi KLHS yang hanya dilakukan pada tahapan analisis adalah jaminan integrasi analisis daya dukung dan daya tampung lingkungan hidup (yang menjadi muatan KLHS RTRW) dalam proses penyusunan konsepsi RTRW provinsi dan dalam proses penyusunan raperda (berupa rumusan pasal-pasal) RTRW provinsi. Dengan demikian ada kemungkinan rekomendasi KLHS untuk perbaikan KRP RTRW tidak ada jaminan pengintegrasiannya dalam raperda RTRW Provinsi. 25

Menurut Wahana Lingkungan Hidup Indonesia (WALHI) Bengkulu melalui Direktur Walhi Bengkulu mengatakan bahwa pemerintah Provinsi Bengkulu belum implementatif terhadap Peraturan Daerah yang sudah berlaku, faktanya bahwa masih belum mampu mengimplementasikan amanat dari Peraturan Daerah Nomor 02 Tahun 2012 tersebut, Peraturan Daerah tersebut hanya dibuat sebagai pemenuhan tugas negara tidak melihat fakta dilapangan serta solusi dari konflik yang ada dilapangan. ${ }^{26}$

Lahan milik PT. PELINDO II yang akan menjadi lokasi pembangunan PLTU tersebut merupakan kawasan Taman Wisata Alam Pantai Panjang dan merupakan konflik yang belum terselesaikan sampai saat ini mengingat bahwa PT. PELINDO II memiliki Seertufikat Hak Pengelolaan Lahan (HPL) sejak tahun 1973 jauh sebelum penunjukan kawasan Taman Wisata Alam. Menurut BKSDA Bengkulu hal ini menimbulkan pemahaman kekuatan secara permanen bagi perambah untuk mempertahankan lahan atau areal yang digarap/diduki/dikelola, karena perambah merasa bahwa keberadaan mereka dikawasan Taman Wisata Alam, sehingga langkah penertiban maupun penegakan hukum untuk penyelesaian sengketa di Taman Wisata Alam di Taman Wisata Alam menjadi semakin sulit. ${ }^{27}$ Direktur Wahana Lingkungan Hidup Bengkulu menambahkan bahwa SK dari Taman Wisata Alam Pantai Panjang baru sebatas penunjukan belum adanya penetapan yang pasti dari Kementerian

24 Kasub Penataan Ruang, Dinas Badan Perencanaan Pembangunan Daerah Provinsi Bengkulu, Wawancara di Bengkulu, tanggal 19-Juni-2017.

25 Edra Satmaidi, "Kajian Lingkungan Hidup Strategis (KLHS) dalam Menjamin Terpeliharanya Daya Dukung dan Daya Tampung Lingkungan Hidup (DDDTLH) Bagi Pembangunan Berkelanjutan", Indonesian Journal Of Dialectics, vol. 5, No 3 Desember 2015, hlm. 130.

26 Direktur Wahana Lingkungan Hidup Indonesia Bengkulu, Wawancara di Sekretariat Walhi Bengkulu, tanggal 16-Juni 2017.

27 Kepala Badan Penelitian dan Pengembangan Hutan Balai Konservasi Sumber Daya Alam Bengkulu, Wawancara di Bengkulu, tanggal 13-Juni-2017.

Dede Frastien: Pengendalian Pemanfaatan Ruang Kawasan Taman Wisata Alam Pantai Panjang Provinsi Bengkulu 
Kehutanan dan Lingkungan Hidup sehingga akan kalah dengan kekuatan hukum dari PT. PELINDO II, hal tersebut berdasarkan pengalaman Wahana Lingkungan Hidup Indonesia Bengkulu ketika melakukan upaya hukum terhadap Cagar Alam Dusun Besar yang dirambah pihak Walhi kalah karena SK dari Cagar Alam tersebut baru sebatas penunjukan. ${ }^{28}$ Apabila Konflik kawasan Taman Wisata Alam Pantai Panjang dengan pihak PT. PELINDO II dilakukan dengan upaya hukum maka hal tersebut tidak akan berhasil dengan kata lain akan kalah dengan kekuatan hukum dari pihak PT. PELINDO II yang diperkuat dengan sertifikat Hak Pengelolaan Lahan (HPL) sejak tahun 1973.

Berdasarkan Peraturan Daerah Nomor 02 Tahun 2012 tentang Rencana Tata Ruang Wilayah Provinsi Bengkulu bahwa pada kawasan yang akan dilaksanakannya pembangunan Pembangkit Listrik Tenaga Uap tersebut merupakan daerah resapan air dalam hal ini merupakan kawasan Taman Wisata Alam Pantai Panjang berdasarkan penunjukan kawasan SK Menteri Kehutanan Nomor 420/Kpts-II/1999. Hal tersebut terbukti pada peta rencana pola ruang Provinsi Bengkulu.

Gambar.:1 Peta Rencana Pola Ruang Provinsi Bengkulu

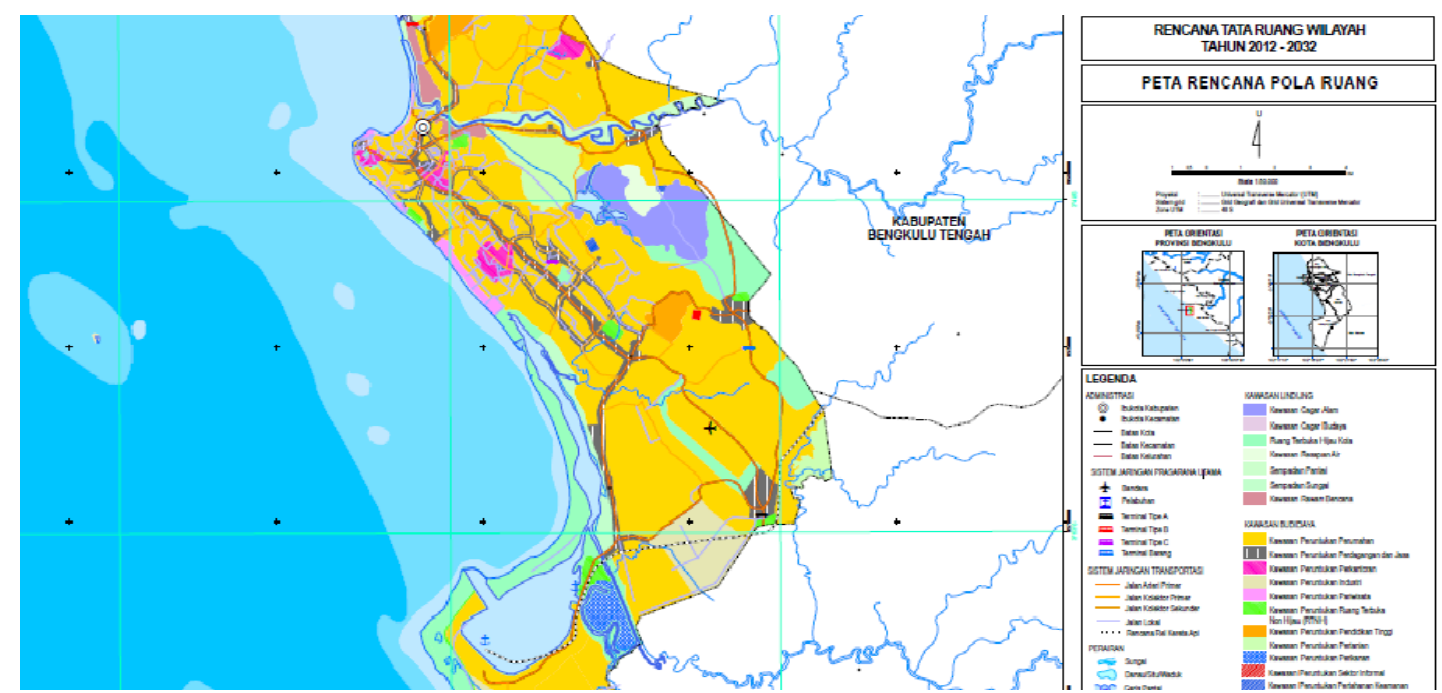

Sumber: Wahana Lingkungan Hidup Indonesia Provinsi Bengkulu

Di lihat pada kerangka acuan Analisis Dampak Lingkungan Hidup PT. Tenaga Listrik Bengkulu terkait rencana pembangunan Pembangkit Listrik Tenaga Uap dan jaringan transmisi, bahwa lokasi tapak proyek PLTU dan beberapa jaringan transmisi menggunakan kawasan resapan air. Seperti terlampir pada dokumen lampiran ANDAL PT. Tenaga Listrik Bengkulu, sebagaimana gambar berikut:

28 Direktur Wahana Lingkungan Hidup Indonesia Bengkulu, Wawancara dengan di Sekretariat Walhi Bengkulu, tanggal 16-Juni 2017.

Dede Frastien: Pengendalian Pemanfaatan Ruang Kawasan Taman Wisata Alam Pantai Panjang Provinsi Bengkulu 
Gambar 2. Peta Rencana Pembangunan Lokasi Tapak Proyek PLTU dan Jaringan Transmisi

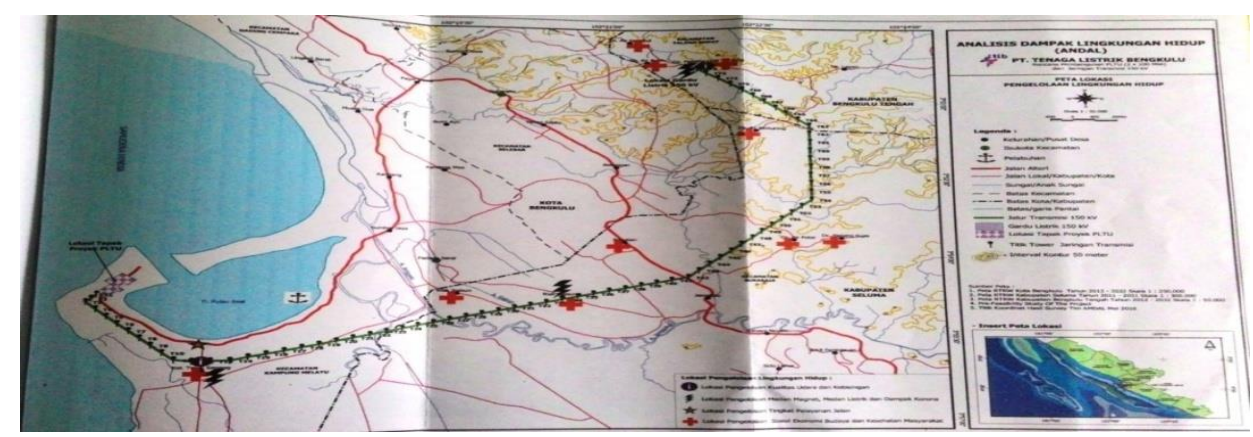

Sumber: Lampiran Analisis Dampak Lingkungan Hidup (ANDAL) PT.

Tenaga Listrik Bengkulu

Peta Dampak Lingkungan Hidup PT. Tenaga Listrik Bengkulu tersebut membuktikan bahwa tapak pembangunan PLTU dan Jaringan Transmisi dilakukan di kawasan resapan air berdasarkan Peraturan Daerah Provinsi Bengkulu Nomor 02 tahun 2012 tentang RTRWP dalam hal ini daerah resapan air yang dimaksud adalah kawasan Taman Wisata Alam Pantai Panjang yang mana kawasan tersebut masih dalam konflik kepada PT. PELINDO, selain bertentangan dengan Peraturan Daerah Provinsi Bengkulu, rencana pembangunan tersebut juga bertentangan dengan Undang-Undang Nomor 25 Tahun 2000 tentang PROPENAS pada bagian B tentang arah kebijakan menjelaskan tentang pengelolaan konservasi sumber daya alam hayati, sebagai berikut: (1)nMengelolah sumber daya alam dan memelihara daya dukungnya agar bermanfaat bagi peningkatan kesejahteraan rakyat dari generasi ke generasi; (2) Meningkatkan pemanfaatan potensi sumber daya alam dan lingkungan hidup dengan melakukan konservasi, rehabilitasi dan penghematan penggunaan, dengan menerapkan teknologi ramah lingkungan; (3). Menerapkan indikatorindikator yang memungkinkan pelestarian kemampuan keterbaharuan dalam pengolaan sumber daya alam yang dapat dipelihara untuk mencegah kerusakan yang tidak dapat balik; (4). Mendeligasikan secara bertahap wewenang pemerintah pusat kepada pemerintah daerah dalam pelaksanaan pengelolaan sumber daya alam secara selektif dan pemeliharaan lingkungan sehingga kualitas ekosistem tetap terjaga, yang diatur oleh undang-undang; (5). Mendayagunakan sumber daya alam untuk sebesar-besar kemakmuran rakyat dengan memperhatikan kelestarian fungsi dan keseimbangan lingkungan hidup, pembangunan yang berkelanjutan, kepentingan ekonomi dan budaya masyarakat lokal serta penataan ruang, yang pengusaannya diatur dalam undang-undang.

Penjelasan Undang-Undang Nomor 25 Tahun 2000 tentang PROPENAS diperlukan pendekatan pembangunan dengan pengembangan lingkungan hidup, yaitu eco-development. Pendekatan ini tidak menolak diubah dan diolahnya sumber alam untuk pembangunan dan kesejahteraan

Dede Frastien: Pengendalian Pemanfaatan Ruang Kawasan Taman Wisata Alam Pantai Panjang Provinsi Bengkulu 
manusia. Tetapi "kesejahteraan manusia" mengandung makna luas, mencankup tidak hanya kesejahteraan material, pemenuhan kebutuhan generasi hari kini, tetapi juga mencakup kesejahteraan nonfisik, mutu kualitas hidup dengan lingkungan hidup yang layak dihidupi (liveble environment) dan jaminan bahwa kesajahteraan terpelihara kesinambungannya bagi generasi depan.dalam pendekatan ini berlaku dalil "apa yang diambil dari alam harus kembali kepada alam, sekurangkurangnya diganti dengan hal berperan serupa kepada alam". ${ }^{29}$

Berdasarkan dokumen kerangka acuan Analisis Dampak Lingkungan Hidup PT.Tenaga Listrik Bengkulu diketahui lokasi PLTU akan dibangun di lahan milik PT. PELINDO II Bengkulu seluas $30 \mathrm{Ha}$, pembangunan 73 tower jaringan transmisi dilakukan sepanjang 22,3 km dan lebar 26 meter atau seluas 57,98 Ha di lahan penduduk berupa kebun karet, kelapa sawit, kebun campuran, sawah dan tegelan. Kebutuhan batu bara untuk pengoprasian PLTU adalah 136, 62 ton per jam atau 3.278,88 ton per hari. Abu hasil pembakarannya diperkirakan 14, 48 ton per jam meliputi 11,58 ton per jam abu terbang dan 2,9 ton per jam abu bawah. Sisa abu terbang yang diolah menggunakan electrostatic precipitator akan dibuang melalui cerobong dengan ketinggian 120 meter dan diameter 4,7 meter, dalam setahun diperkirakan volume abu batubara yang dihasilkan sekitar 20.162 ton. Air yang akan digunakan untuk pengoprasian adalah air laut sebanyak 52.230 meter kubik per jam, air bekas pengoprasian yang bersuhu 40-45 derajat celcius akan dibuang kembali ke laut melalui pipa. ${ }^{30}$

Apabila PLTU tersebut telah beroperasi keteracaman pada kepunahan ekosistem Taman Wisata Alam Pantai Panjang tidak dapat dihindari lagi pada tingkat pembuangan air 40-45 derajat celcius akan menyebabkan kepunahan pada potensi alam yang ada di Taman Wisata Alam Pantai Panjang. Berdasarkan data Balai Konservasi Sumber Daya Alam Bengkulu Tahun 2015, Flora dan Fauna tersebut meliputi: (a) Vegetasi Hutan Pantai, meliputi cemara laut, ketapang, waru; (2) Panorama Pantai pasir putih; (3) Hutan Mangrove; (4) Flora dan fauna meliputi aves, primata, terumbu karang.

Selain akan berdampak kepada Taman Wisata Alam Pantai Panjang, perencanaan pembangunan PLTU yang menggunakan areal daerah resapan air tersebut akan memberikan dampak negatif pada warga kelurahan Teluk Sepang yang mana berdasarkan Profil Kelurahan Teluk Sepang 90\% mata pencaharian warga adalah petani dan nelayan limbah pembuangan meliputi abu dan pembuangan air dengan suhu 40-45 derajat celcius, akan menyebabkan perusakan terumbu karang dan hasil tangkapan pasti akan menurun, selain itu 3.500 jiwa penduduk Kelurahan Teluk Sepang terancam terkena racun debu batu bara. hlm. 130

${ }^{29}$ Emil Salim, Pembangunan Berwawasan Lingkungan, LP3ES, Cetakan ke-1, Jakarta, 1986,

30 Dokumen Kerangka Acuan Analisis Dampak Lingkungan Hidup PT. Tenaga Listrik Bengkulu. Rencana Pembangunan PLTU dan Jaringan Transmisi.

Dede Frastien: Pengendalian Pemanfaatan Ruang Kawasan Taman Wisata Alam Pantai Panjang Provinsi Bengkulu 
Penerapan prinsip pembanguanan berwawasan lingkungan sangat penting bagi pemerintah Provinsi Bengkulu, dalam upaya perlindungan Taman Wisata Alam Pantai Panjang dan perencanaan pembangunan. Dengan terlaksananya pembangunan berwawasan lingkungan dan terkendalinya pemanfaatan sumber daya alam secara bijaksana merupakan tujuan utama pengelolaan lingkungan hidup. Untuk mencapai tujuan ini, sejak awal perencanaan kegiatan sudah diperkirakan perubahan rona lingkungan akibat pembentukan suatu kondisi lingkungan baru, baik yang menguntungkan maupun yang merugikan yang timbul sebagai akibat diselenggarakannya kegiatan pembangunan. ${ }^{31}$ Kita yakin bahwa pada akhirnya pembangunan dan pelestestarian mempunyai tujuan yang sama, yaitu: pengelolaan sumber alam sebijaksana mungkin demi tercapainya mutu hidup manusia yang setinggi mungkin. Apa yang baru saya disebutkan tadi pada dasarnya adalah definisi konsep yang terus berkembang yang pada umumnya disebut (eco-development), dan yang didasarkan pada premis, bahwa setiap orang berhak mengenyam buah pembangunan dan berhak menikmati lingkungan yang sebaik mungkin. ${ }^{32}$

Dengan penerapan prinsip pembangunan berwawasan lingkungan secara bijaksana, maka akan terselenggara perlindungan dan pelestarian Taman Wisata Alam Pantai Panjang, terhindar dari kerusakan dan kepunahan serta dapat terus menjadi penyangga kehidupan disekitarnya. Namun sebaliknya perubahan pemanfaatan ruang yang tidak memperhitungkan aspek keseimbangan geobiofisik akan berakibat kepada Pemanfaatan Ruang. Seperti rencana pembangunan PLTU yang tidak memperhatikan aspek keseimbang geobiofisik akan berakibat kepunahan dan merusak ekosistem. Serta kawasan resapan air seperti Taman Wisata Alam Pantai Panjang tidak mampu lagi untuk menyimpan air dan berdampak pada wilayah sekitar Taman Wisata Alam Pantai Panjang. Agar pemanfaatan ruang sesuai dengan rencana tata ruang dilakukan pengendalian melalui, kegiatan pengawasan dan penertiban pemanfaatan ruang. Pengawasan yang dimaksud adalah usaha untuk menjaga kesesuaian pemanfaatan ruang dengan fungsi ruang yang ditetapkan dalam rencana tata ruang. Penertiban dalam ketentuan ini adalah usaha untuk mengambil tindakan agar pemanfaatan ruang yang direncanakan dapat terwujud sesuai dengan ketetapan. ${ }^{33}$ Apabila Pemanfaatan Ruang telah sesuai dengan rencana tata ruang maka perlindungan terhadap Taman Wisata Alam Pantai Panjang dapat terlaksana dan apabila pemerintah Provinsi Bengkulu dengan tegas menertibkan Pemanfaatan Ruang yang tidak sesuai dengan fungsi ruang maka akan terwujudnya tertib tata ruang.

${ }^{31}$ Alam Setia Zain, Hukum Lingkungan Konservasi Hutan Dan Segi-Segi Pidana, Jakarta, PT. Rineka Cipta, 1997, hlm.10.

32 Emil Salim,Loc.cit.

${ }^{33}$ Rinaldi Mirsa, Elemen Tata Ruang Kota, Yogyakarta,Graha Ilmu,2012, hlm. 40.

Dede Frastien: Pengendalian Pemanfaatan Ruang Kawasan Taman Wisata Alam Pantai Panjang Provinsi Bengkulu 


\section{PENUTUP}

\section{Simpulan}

Pengendalian Pemanfaatan Ruang dalam rangka perlindungan kawasan Taman Wisata Alam Pantai Panjang berdasarkan Peraturan Daerah Nomor 02 Tahun 2012 Tentang Rencana Tata Ruang Wilayah Provinsi Bengkulu Tahun 2012-2032, belum dapat berjalan optimal serta belum mampu memberikan perlindungan terhadap kawasan Taman Wisata Alam Pantai Panjang. Terbukti dengan pemerintah Provinsi Bengkulu yang tidak dapat melakukan Pemanfaatan Ruang sesuai dengan Perencanaan Ruang dalam melakukan perencanaan pembangunan, dan belum mampu menertibkan bangunan-bangunan yang tidak sesuai dengan fungsi Taman Wisata Alam Pantai Panjang sesuai yang diamanatkan Peraturan Daerah Nomor 02 Tahun 2012. Terdapat dua faktor penghambat dalam melakukan pengendalian pemanfaatan ruang dalam rangka perlindungan kawasan Taman Wisata Alam Pantai Panjang, yang pertama faktor internal yaitu pemerintah daerah Provinsi Bengkulu, kurangnya koordinasi antara pemerintah Provinsi Bengkulu dengan Balai Konservasi Sumber Daya Alam, dan belum terdapat peraturan khusus tentang arahan zonasi tata ruang. Faktor penghambat yang kedua faktor eksternal, yaitu konflik pemanfaatan kawasan Taman Wisata Alam Pantai Panjang dan rendahnya kesadaran hukum masyarakat.

\section{Saran}

Pemerintah Provinsi Bengkulu dapat lebih konsisten dalam penerapan Peraturan Daerah Nomor 02 Tahun 2012 tentang Rencana Tata Ruang Wilayah Provinsi tahun 2012-2032, agar implementasi Peraturan Daerah tersebut dapat memberikan perlindungan terhadap kawasan Taman Wisata Alam Pantai Panjang. Dalam menyelesaikan konflik-konflik tumpang tindih kawasan dan melakukan tertib ruang pada bangunan-bangunan yang tidak sesuai dengan fungsi Taman Wisata Alam, Balai Konservasi Sumber Daya Alam Bengkulu haruslah lebih serius,dengan mengacu kepada Undang-Undang Nomor 5 Tahun 1990 tentang Konservasi Sumber Daya Alam Hayati dan Ekosistemnya yang dipaduserasikan dengan Peraturan Pemerintah Nomor 108 Tahun 2015 tentang Pengelolaan Kawasan Suaka Alam dan Kawasan Pelestarian Alam, sehingga terwujudnya perlindungan dan pelestarian Taman Wisata Alam Pantai Panjang.

\section{DAFTAR PUSTAKA}

Abdulah Marlang dan Rina Maryana, (2015), Hukum Konservasi Sumber Daya Alam Hayati dan Ekosistemnya, Jakarta: Mitra Wacana Media.

BKSDA Bengkulu, (2015), Ekspose Hasil Kegiatan Identifikasi dan Potensi Konflik di TWA Pantai Panjang Pulau Baai Reg. 91 Kota Bengkulu, Laporan Perjalanan Dinas, Bengkulu: BKSDA Bengkulu.

Dede Frastien: Pengendalian Pemanfaatan Ruang Kawasan Taman Wisata Alam Pantai Panjang Provinsi Bengkulu 
Alam Setia Zain, (1997). Hukum Lingkungan Konservasi Hutan Dan Segi-Segi Pidana, Jakarta, PT. Rineka Cipta.

Direktur Wahana Lingkungan Hidup Indonesia Bengkulu, (2017). Wawancara di Sekretariat Walhi Bengkulu, tanggal 16-Juni.

Dokumen Kerangka Acuan Analisis Dampak Lingkungan Hidup PT. Tenaga Listrik Bengkulu. Rencana Pembangunan PLTU dan Jaringan Transmisi

Edra Satmaidi, (2015), "Kajian Lingkungan Hidup Strategis (KLHS) dalam Menjamin Terpeliharanya Daya Dukung dan Daya Tampung Lingkungan Hidup (DDDTLH) Bagi Pembangunan Berkelanjutan", Indonesian Journal Of Dialectics, Vol. 5 (3) Desember.

Emil Salim, (1986). Pembangunan Berwawasan Lingkungan, Jakarta.LP3ES, Cetakan ke-1, Jakarta

Hanif Nurcholis dkk, (2009), Perencanaan Partisipatif Pembangunan Daerah, Jakarta: PT. Gramedia Widiasarana Indonesia.

Hasni, (2010), Hukum Penataan Ruang dan Penatagunaan Tanah ,Edisi Kedua, Jakarta: PT RajaGrafindo Persada.

Iskandar, (2011), "Aktualisasi Prinsip Hukum Pelestarian Fungsi Lingkungan Hidup Dalam Kebijakan Perubahan Peruntukan, Fungsi, dan Penggunaan Kawasan Hutan", Jurnal Dinamika Hukum, Vol. 11 (3).

Iskandar, (2015),Hukum Kehutanan, Bandung: CV. Mandar Maju

Kasub Penataan Ruang, Dinas Badan Perencanaan Pembangunan Daerah Provinsi Bengkulu, (2017). Wawancara di Bengkulu, tanggal 19Juni.

Kepala Badan Penelitian dan Pengembangan Hutan Balai Konservasi Sumber Daya Alam Bengkulu, (2017). Wawancara di Bengkulu, tanggal 13-Juni.

Kepala Bidang Destinasi Pariwisata Dinas Pariwisata Provinsi Bengkulu, (2017), Wawancara, tanggal 14-Juni.

Kepala Bidang Perencanaan dan Tata Hutan Dinas Lingkungan Hidup dan Kehutanan Provinsi Bengkulu, (2017), Wawancara di Bengkulu, tanggal 16-Juni.

N.H.T Siahaan, (2004), Hukum Lingkungan Ekologi Pembangunan, Jakarta, Penerbit Erlangga, Edisi. 2.

Rinaldi Mirsa, (2012). Elemen Tata Ruang Kota, Yogyakarta, Graha Ilmu.

Dede Frastien: Pengendalian Pemanfaatan Ruang Kawasan Taman Wisata Alam Pantai Panjang Provinsi Bengkulu 
Supremasi Hukum :Jurnal Penelitian Hukum

p-ISSN: 1693-766X ; e-ISSN: 2579-4663, Vol. 27, No. 1 Januari 2018, 1-22

http://www.konservasionis.com/2016/05/eksplorasi-twa-pantai-panjangkoservasi.html diunduh pada hari Jum'at 24/03/2017 pukul 19:20 WIB 